\title{
Impact of COVID - 19 on Sustainability of Civil Society Organizations in the Western Balkan Region
}

Abstract: Authors of the study have tried to outline the impact of COVID 19 over the civil society sector in the Republic of North Macedonia. In this complex situation of a global pandemic they have focused on the allocation of funds. In addition, the cooperation between government institutions and citizens' associations in carrying out activities to deal with pandemic has also been examined. Contentanalyses have been applied to examine the regulations in which participation of the citizens' associations in the context of the pandemic is determined. In addition, comparative methods have also been applied to determine the degree of NGOs involvement in the use of budget and other donated funds. Finally, qualitative methods are also used to evaluate whether these funds have been the right choice of the associations in context of their sustainability to create opportunities to carry on with activities.

When reviewing the whole paper, an impression is created that more comprehensive research with a larger number of respondents / NGOs is needed. Thus, through a case study answers will be provided to the issue of whether these NGOs are really non-profit or not. Also, whether in a certain period they fulfill certain government goals or other interests while profiting directly or indirectly on different bases.

\footnotetext{
* Dr Romeo Drobarov is employed in the Ministry of Interior Affairs of the Republic of North Macedonia. The research component and reflection in the paper are personal views of the author and are not related to the institution he comes from (drobarov_ga@yahoo.com).

** Biljana Popovska, MA is an advisor at the Ministry of Defense, PhD student at the University of Bucharest, Romania (bpopovska@yahoo.com).

*** Dr Igor Gelev is an officer in the rank of lieutenant colonel, employed in the Army of the Republic of Northern Macedonia. The research component and reflections in the paper are personal views of the author and are not related to the institution he comes from (igelev@yahoo.com).
} 
Finally, the authors in specific conclusions and recommendations determine a possible course of further action in terms of more transparent, more efficient and more comprehensive work of the NGOs.

This research was supported by WBF and Ministry of Foreign Affairs of Japan, 2021.

Keywords: NGO, COVID-19, pandemic, sustainability.

\section{Introduction}

The pandemic caused by the COVID-19 virus, which has had consequences for the global health, economic and social crisis, has brought significant challenges to civil society in the Western Balkans. It is exactly in such crisis situations, when developing countries, among which are the ones from Western Balkans including the Republic of North Macedonia, where providing the welfare of people from socially vulnerable categories largely depends on the availability of resources provided by NGOs.

Main purpose of having associations and foundations as non-governmental organizations is to contribute to maintaining peace, harmony and prosperity of the society through participatory democracy, rule of law, balanced and sustainable socio-economic development, non-violence and respect. With this primary goal as a starting point, while faced with the challenge of COVID-19 and the danger this pandemic brings, associations and foundations have been the first to recognize the need for urgency, and taking solidarity steps in their communities. ${ }^{1}$ On the other hand, at the start of the pandemic, all countries in the Western Balkans declared a state of emergency with severe restrictions on movement aimed at preventing the spread of the virus. Consequently, Civil Society Organizations (CSOs) across the Western Balkans have struggled to adjust their operations and priorities to respond adequately to the emergency and meet the immediate needs of their constituencies while striving to reach their goals and address the lack of funding and support from states and donors - reasons that limited the implementation even of the basic plans and programs of the associations and foundations ( $\mathrm{Ne}-$ shikj, I \& Spasovska, 2020).

1 Government of the Republic of Northern Macedonia, Council for Cooperation with and Development of the Civil Society (2020, April). Information on measures taken by associations and foundations in dealing with the COVID-19 pandemic and request for inclusion of representatives of associations and foundations in the relevant "anti-crisis bodies". Skopje, p.2. 
Nonetheless, changes in civil society are emerging even in countries with positive trends before the crisis, such as the Republic of North Macedonia. Because of the states of emergency, all countries in the region made decisions on coronavirus response measures without discussions in parliaments or the involvement of different stakeholders (FES, 2020).

Management activities in supply chain humanitarian initiatives involve versatile processes through which NGOs appeal to interested parties to acquire resources (Prasad et al., 2016). Mutual humanitarian aid activities are represented by (a) fundraisers through individual donations (Bekkers and Wiepking, 2011), organizational donations (Ballestros and Gatignon, 2019), and public donations (Ceptureanu et al., 2018); (b) the supply of services and goods to vulnerable categories (Weisbrod, 1975; Salamon, 1987); (d) participation of volunteers (Nemţeanu and Tarcza, 2016; Touley and Hooks, 2020), and (e) public information campaigns through social marketing (Nemțeanu1, S.M. \& Dabija D.C. 2020).

Schwartz and Yen (2017) point out a connection between sustainable development and socio-economic crises, highlighting the direct role of nongovernmental organizations (NGOs) in offering support to various vulnerable groups. In practice, NGOs are entities which, in extreme situations, can provide vulnerable groups with the material and human resources needed in overcoming adversity (Prasad et al., 2016; Schwartz and Yen, 2017). In this manner, the NGO becomes a key stakeholder between public institutions and the population (Portney and Cuttler, 2010). The NGO is both a relevant resource provider for public institutions and an active participant supporting vulnerable groups and ensuring their access to necessary resources.

In the study "Impact of COVID-19 on Nepali Civil Society Organizations", authors Dipendra KC, Bijay Bhandari and Jay Jung Mahat give an example of the sustainability of the civil sector in the geographical area of Nepal, which differs in number and mentality from the Republic of North Macedonia. In the study they have analyzed the process of providing assistance from direct donors or organizations in the context of the COVID 19 pandemic in a defined period. However, analysis does not provide solution related to the conditions and legal regulations and circumstances that affect the process of communication and allocating grants to the civil sector. In addition, it does not provide scientifically proven research findings that could predict the end or duration of the pandemic. Such development of events and the uncertainty arising from the corona crisis calls into question the survival of NGOs. 
At the same time, quest for answers to these questions leads us to the purpose of this research paper, which is to identify the problems and challenges caused by the COVID-19 virus the countries of the Western Balkans have to deal with. Given the complexity of the overall situation, and difficulties faced by national governments, questions about the role and power of the non-governmental sector as an important factor within societies arise. For that purpose, focus of this research will be the work of the non-governmental sector in the Republic of Northern Macedonia during the pandemic crisis. To that end, status of citizens' associations and foundations was analyzed as a special goal. In addition, reasons why citizens' associations are not able to consistently implement their activities, as well as finding new opportunities and solutions to continue the engagement and adapt to the new situation have also been analyzed.

A practical goal is to determine the perception of the efficiency and sustainability of the civil sector by elaborating regulations, reviewing, processing and analysis of certain statistical data, as well as by using processed semi-interviews (of staff involved in the activities of the non-governmental sector). Hence, to provide evidence and deliver recommendations for further support to the NGO sector in overcoming operational shortcomings during the pandemic. Also, by reviewing the content of the decisions taken it will become visible whether the entire process was transparent and whether the awarding of grants was in accordance with the positive legal regulations. In addition, it will become clear whether restrictions on grouping of people (more than 4) and movements have influenced the joint work of the associations. Whether the time between publishing the public call for awarding projects' grants and the application deadline was sufficient for timely information, project preparation and application of non-governmental organizations?

\section{Methods and methodology}

Detected problem in this theoretical-empirical research is related to the conditions about functioning and survival of the non-governmental sector during the COVID-19 pandemic. The subject of this research will be analyzed in the period from March to December 2020 in the Republic of North Macedonia as part of the Western Balkans.

Complexity of the research have initiated several methods of research work to be used, especially in the part that refers to the estab- 
lished institutional concepts of interaction between donors and citizens' associations and the operational concept of implementing program activities. Thus, in the first phase, data were collected through analysis of professional literature, collection of documents, their arrangement, analysis, i.e. processing and interpretation of data. It is worth to mention that there is not sufficient literature for such studies in the Republic of North Macedonia. However, combined use of available domestic and foreign literature along with the statistical data and researches, created conditions to reach a new scientific knowledge.

The problem of the research has a certain scientific and practical significance, because the findings about decisions and procedures related to functioning of the civil sector in conditions of COVID-19 pandemic, will find its practical use to establish better cooperation procedures between NGOs and institutions for their (socio-economic) sustainability and further development.

Theoretical nature of the subject of the research determined the application of the descriptive model which was used to give a broader description of the concept of using funds in conditions of COVID-19 pandemic, transparency of procedures and balance in the distribution of funds to citizens' associations through institutions or direct donors. It was then used to tackle the conditions for cooperation between citizens' associations and institutions and, in addition, to analyze the impact of the adopted procedures and protocols on the availability of funds and their purposeful use during the COVID pandemic.

Content analysis has been applied in the analysis of government minutes, decisions and decrees, analysis of previous research, analysis of statements and a range of other data presented in similar research work and websites.

In the next phase of the research, data obtained from the online survey from the organizations in Macedonia were summarized. In total, seven organizations provided answers to the structured questionnaire. Organizations were randomly selected from the existing register of non-governmental organizations with different areas of activities but also from different geographical areas of the Republic of North Macedonia. Questionnaire was structured based on previous research. In line with the set theses 23 questions were defined. Respondents were initially contacted by telephone. Later, they were invited to respond to the electronic questionnaire via established online platform. Gathered data were further analyzed and are presented in the results chapter. 
In addition to the survey, semi-interview as a method was used in the final stages of this research. To be more precise, staff with different roles and positions in the civil society sector but directly involved and familiar with the process of announcing public calls were interviewed. They were asked to comment briefly on specific issues related to the coordinated work of citizens' associations as a link between citizens and state institutions in peacetime and during emergencies such as the COVID-19 pandemic. Additionally, it was expected that they present their views and perceptions about the situation regarding the experiences gained so far, problems during the operation, availability of funds and dealing with future challenges and expectations. The interviews were conducted according to the highest ethnic standards, i.e. with a guarantee of anonymity and confidentiality of the respondents.

Graphical models were used in a form of diagrams and spreadsheets in order to present the opinions of respondents who are practitioners and those involved in the processes of correspondence between the institutional and civil society. Hence, to point out the response to issues related to working conditions in the crisis, maintaining staff and capacity to survive as well as how NGO sector adapts now and ideas for the future.

The comparative method was used in order to accomplish partial qualitative and quantitative selection and analysis of report data. Results were mutually analyzed, semantically linked and compared by using Semantic Text Analysis Software. However, this research contains a series of limitations, one of which is the explicit focus of the case on the Republic of North Macedonia. An additional limitation is that the analysis is a so-called surface survey, which basically consists of insufficient transparency of the activities of institutions and the non-governmental sector in different periods and situations.

\section{Analysis and results}

As a response to the pandemic, governments of the countries in the region, including the government of the Republic of North Macedonia, have adopted protocols and measures, which further have had impact on the provision of services and the overall functioning of the nongovernmental sector.

Thus, most of the measures envisaged in the regulations (adopted by the government of Republic of North Macedonia, which refer to the ban on the movement of persons and restriction of transport and 
transportation but are indirectly related to the work of the civil sector) refer to the period from March 21 to 31 December 2020. In the Republic of North Macedonia this period is known as a period of adaptation to the state of emergency which moved the balance of the political power in the state into the hands of the government (FES, 2020).

On June 5, 2020, the 21st (on-line) session of the Council for Cooperation with and Development of the Civil Sector was held. During this session, the Council confirmed a positive opinion upon the Draft Program for financing the program activities of the associations and foundations for measures to deal with the COVID-19 crisis. Draft Decision on the criteria and the procedure for allocation of funds for financing the program activities of associations and foundations from the budget of the Republic of Northern Macedonia for measures to deal with the COVID-19 crisis was set. Information materials were prepared by the Department for Cooperation with Non-Governmental Organizations. They were enhanced with proposals from civil society organizations previously consulted through the members of the Council. The Council nominated two of its members from the ranks of the Civil Society Organizations to participate in the work of the Commission for distribution of funds, with the right to vote. ${ }^{2}$

General analysis of the developments is presented in the regional review," Balkan Civil Society Development Network, accessed October 9, 2020, which states that the Western Balkans region lacked systematic and consistent approach to supporting the work of NGOs. As an example, the Government of Republic of Northern Macedonia was sending mixed signals, i.e. after the previous cut of the funds for the civil sector, the government announced a public call of a total value of 570000 dollars for the civil sector to deal with the corona virus. The public call was announced on June 6, 2020 and lasted until June 11, 2020 at 12 o'clock. $^{3}$ The funds were distributed among 40 out of about 15478 registered citizens' associations in the Central Register of the Republic of North Macedonia ${ }^{4}$.

During the $22^{\text {nd }}$ online session of the Council for Cooperation with and Development of the Civil Sector (hereinafter the Council) held on 19 June 2020, the "Report on the participation of the members of the Council in the work of the Commission for distribution of funds aimed for financial support of associations and foundations for measures to

\footnotetext{
$2 \mathrm{https} / /$ www.nvosorabotka.gov.mk/?q=mk/node\&page $=6$

$3 \mathrm{https}: / /$ www.nvosorabotka.gov.mk/?q=mk/node $/ 423$

$4 \mathrm{https}: / /$ www.crm.com.mk
} 
deal with the COVID-19 crisis" was adopted. ${ }^{5}$ Wording of the Report prepared by the Council as a government body cites that the decisionmaking process and the announcement of the call for distribution of funds were exclusively transparent.

In order to work transparently and cover a number of topics of importance to the general public, the Council for Cooperation with and Development of the Civil Society Sector during its $25^{\text {th }}$ session, held on December 2, 2020 calls on civil society organizations to actively contribute to the work of the Crisis Board. ${ }^{6}$

All of these activities by the government and other bodies are to show the involvement of the non-governmental sector in the processes that lead to dealing with the pandemic. It should be emphasized that a non-governmental organization's job is not to replace the government, but rather to complement the government by filling gaps in both society and development which it has failed to provide (Islam, 2016).

Preliminary process of informing the civil sector about the public call announcement is essential for timely preparation and receiving funds for a certain project i.e. funds that would be important for the survival and maintenance of the NGOs. At the same time, the communication specified in the mission of the NGOs is a major driver in obtaining funds for further achievement of the set goals.

However, a clear distinction needs to be made between the governmental and non-governmental sector with special missions, capacities and modes of operation that support each other in the process of dealing with the consequences of the COVID-19 pandemic.

In the analysis of the adopted protocols, certain restrictions on gathering people indoors, access to certain premises and contacts with persons, reduction of movements due to restrictions on transport and transportation are just some of the factors that influenced the (not) implemented activates of the civil sector.

Thus, with the allocated funds, associations and foundations realized activities aimed at granting humanitarian aid to the most vulnerable people in a form of hygiene items and food packages. They also provided legal aid to protect the labor rights of the affected categories of people in crisis. In addition, actively work on the lines of support for victims of domestic violence, and provide legal assistance to victims of hate speech, provide support through open educational platforms to maintain

5 https://www.nvosorabotka.gov.mk/?q=mk/node\&page $=5$

$6 \mathrm{https}$ //www.nvosorabotka.gov.mk/ 
a level of equal access to education, provide direct financial assistance to citizens who have no revenues, analyze and prepare documents to deal with the rise of fake news, economic measures to be taken for more rational spending of public money during the crisis, etc. ${ }^{7}$

At a time when the whole world has had to adapt to the new situation with the coronavirus, civil society organizations proved to be among the first to recognize the urgency and need as well as to act accordingly. They have taken solidarity steps in their communities. However, they were faced with the challenge of closing their offices, adapting their services to isolation while demonstrating a high level of innovation. ${ }^{8}$ Organizations in the Republic of North Macedonia are generally small, which is typical for non-governmental organizations in the region.

As shown in Chart 1, during the critical period in the largest percentage of NGOs the number of employees or volunteers ranged from 5-7 people. Based on the data from the surveyed NGO's during the crisis, $43 \%$ of the respondents (i.e. NGOs) had an outflow of staff of 1-3 people, which is a significant number given that we previously mentioned that the number of employees or volunteers is 5-7 people

\section{Chart 1}

Number of outgoing staff in the course of 2020

7 responses
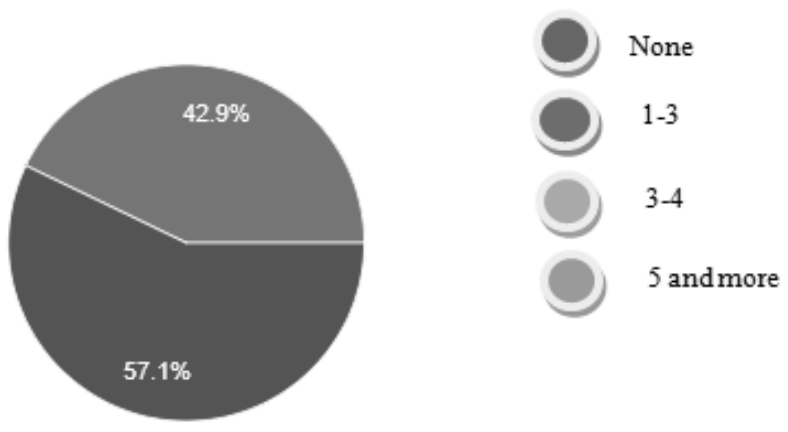

7 Government of the Republic of North Macedonia, Council for Cooperation with and Development of the Civil Society Sector (April, 2020). Information on measures taken by associations and foundations in dealing with the COVID-19 pandemic and request for inclusion of representatives of associations and foundations in the relevant "anti-crisis bodies", Skopje.

$8 \mathrm{https} / / /$ civicamobilitas.mk/covid-19/ 
An analysis was also made of the number of infected persons employed or engaged in NGOs, and as a percentage it is shown in Chart 2.

Chart 2

Personnel infected with COVID 19

7 responses

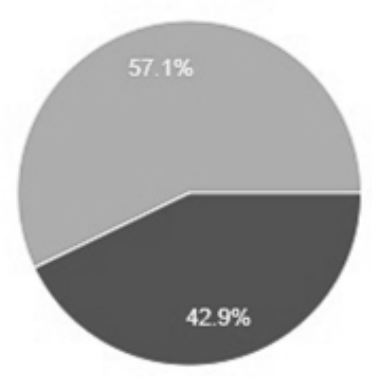

Less than a third

More than a third

Not at all

Given that less than half of the staff in the respondent organizations was infected with the COVID-19 virus, they were asked if they would have difficulty to survive if the pandemic continues and what would be the reasons for it. More than half of the organizations answered that they would be able to survive and half of them that they would have some difficulties.

Chart 3

7 responses
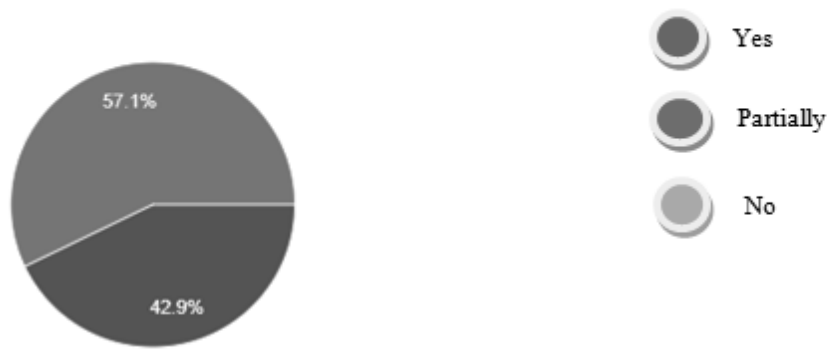

However, almost all organizations responded that the main reason for this were financial problems. 
Chart 4

What are the reasons for it?

7 responses

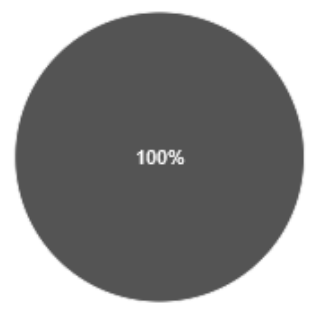

Financial means

Lack of personnel

Conditions imposed by the govemment

Fear from the virus

Organizations mainly depend on domestic and international funds. Only $14.3 \%$ of the organizations have received some sponsorships from the government budgets, while the rest of the financing was through other entities. Self-financing is not so common.

Some of the sustainability parameters are expressed through the number of activities performed by citizens' associations.

At the time of the pandemic, $14.3 \%$ of the surveyed organizations performed 3 or more activities, while in the remaining $85.7 \%$ it was reduced to 1-2 activities per organization.

In general, the organizations worked on regular activities because the number of newly received projects during 2020 was 1 to 2 projects per organization.

The change of activities was related to the priorities of the target groups towards which the organizations provide support, but also depended on the available resources and capacities such as the need for equipment that will fill the gaps impeded by the adopted protocols.

Chart 5

Whether there were newly received projects in 2020 ?

7 responses

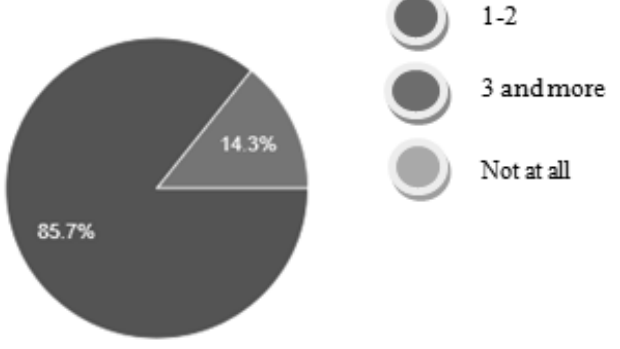


In fact, more than half of the respondent organizations answered that the technological communication devices enabled them to partially perform the activities and $57.1 \%$ of the total number of respondentorganizations answered that they need to purchase new technological communication equipment.

Chart 6

Did you have a need to procure technological and communication devices?

7 responses

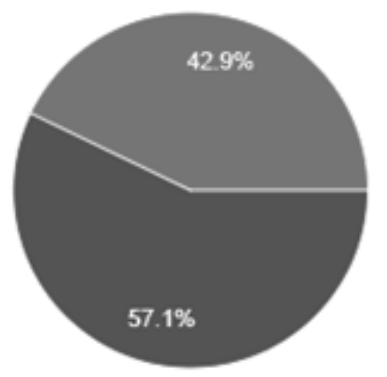

Yes

No

The need for training in the use of devices was supported by more than half of the organizations while $42.1 \%$ fully supported holding of webinars as substitute for the traditional format of organizing seminars.

Chart 7

Do you think that by using webinars you can implement part of your activities?

7 responses

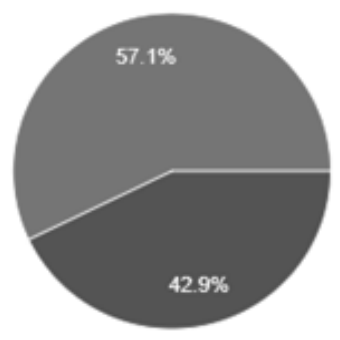

Yes

Partially

No 
NGOs expected the greatest help from government institutions as measures for functional sustainability in the process of implementing action plans during the critical period,. To that end, in their comments they cited the need for greater assistance and support from government institutions through subsidies and more frequent public calls for grants.

Correspondence as the first parameter for support of government institutions to NGOs was expressed through informing about public calls for projects.

To this issue most of the associations $(85.7 \%)$ reported that they were informed in one of the electronic ways. In the second phase of cooperation in the part, which refers to transparency and equality in awarding projects after public calls, respondents gave different answers: $14.3 \%$ rated it as insufficient, $28.6 \%$ as sufficient, $14.3 \%$ good, $42.9 \%$ very good and no one replied that this procedure was great.

\section{Chart 8}

Evaluate the transparency and equality in the procedures for allocating funds from the public calls?

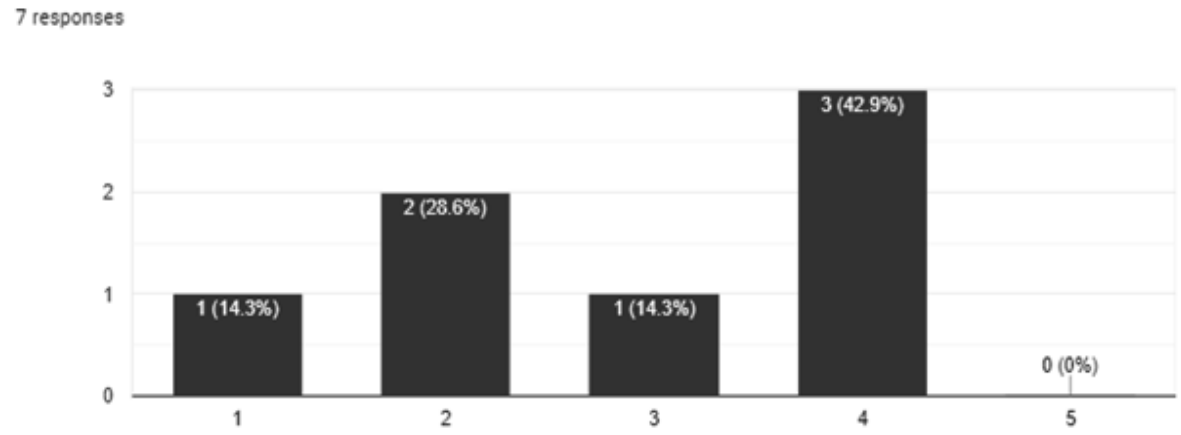

Part of the analysis tackled the cooperation of the non-governmental sector and the governmental institutions. Highest percentage, 57.1\% assessed it as good, $14.3 \%$ as insufficient, $28.6 \%$ as very good and $0 \%$ as sufficient and excellent. 


\section{Chart 9}

Evaluate the cooperation between the non-governmental associations and governmental institutions during the pandemic ( 1 is the least factor, 5 the greatest).

7 responses

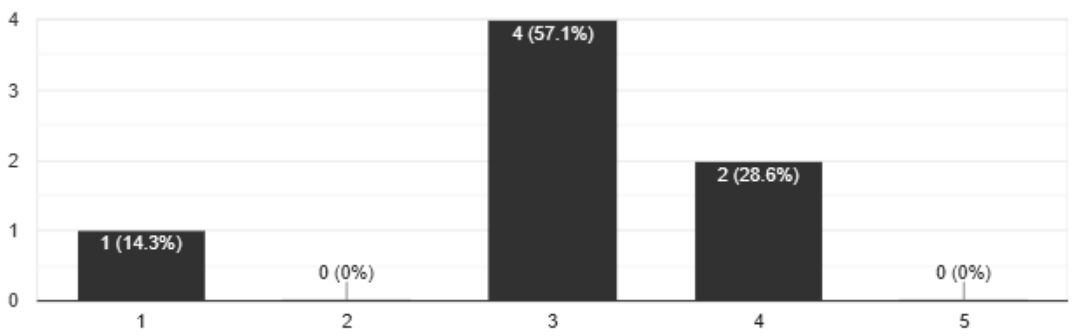

Satisfaction and motivation of the staff to commit and continue with the activities within the organization under the influence and in conditions of the pandemic are shown in Chart 10, where $57.1 \%$ of the respondents are moderately satisfied while the remaining $42.9 \%$ are very satisfied.

Chart. 10

Motivation (satisfaction) of the personnel

7 responses
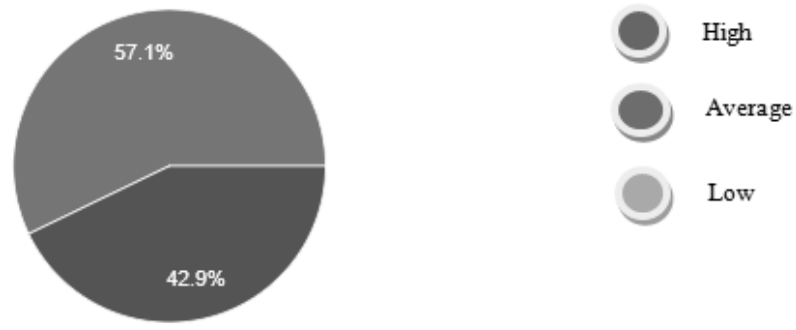

"Insufficient commitment to timely collective protection led by government entities with the help of non-state actors has increased the consequences of the pandemic." President of the NGO

"Planned and organized action of the non-governmental sector is a prerequisite for successful management in crisis situations. At the same time, the financial means are useless without a previously established critical infrastructure for systemic action in emergency situations" President of the foundation. 


\section{Conclusion}

Still deteriorating situation and the consequences of the COVID-19 pandemic continue to cause negative social and economic implications not only among the citizens of the Republic of North Macedonia but also in the wider region of the Western Balkans.

The analysis provided in the research showed that even before the beginning of the crisis, countries of the Western Balkans could not adequately cope alone with the already complex social, health and economic problems in their countries.

First phase of the reaction, confirmed that the government authorities tried to centralize their competencies and activities towards themselves and did not show sufficient interest and readiness to adequately use the capacities of non-governmental organizations in the process of providing assistance to those most in need at that time. Later, the management of situations from the side effect of the coronavirus pandemic showed that a comprehensive response must be established by delegating activities and involving associations as representatives of civil society in coordination with state bodies and the bodies responsible for this issue.

With the increase in the number of infected and dead people, the need for more complicated actions than the already established model of crisis management has emerged. Nevertheless, public institutions, with some exceptions, bypassed the involvement of civil society in their daily organizational engagements.

It should be noted that the support of the government in the allocation of funds was insufficient, expressed through the perspective of lack of interest in cooperation with the civil sector and insufficient transparency and equality in the allocation of funds. Undoubtedly, the very small percentage of organizations that did receive a project announced in the government's public call for grants to deal with the pandemic was brought to the surface by the research as a detected issue.

Regarding the fact that there is not enough publicly available data on the activities of government institutions in that area it seems that the respondents were satisfied with the information of government institutions regarding public calls. However, the dissatisfaction of the respondents to allocation of government funds and in relation to the above leaves room for doubt that the funding of NGOs and their representatives takes place under insufficient external supervision despite the above criteria and public calls. So, despite the involvement 
of civil society representatives the calls were announced in a relatively short reporting period without prior analysis and assessments that would reflect the needs of citizens directly or indirectly affected by the COVID-19 pandemic. Adequate to this solution to the problem which is also recognized in the content of the feedback from the respondents, it is a fact that the support of government institutions to the work and sustainability of the civil sector is insufficient.

From the aspect of fulfilling the general goals and in the context of the institutions' attitude towards the non-governmental sector, the expected results were not obtained. On the contrary, negative implications were caused as a result of bias, inadequate and disproportionate involvement in joint policies and operations of the non-governmental sector, in the overall process of providing assistance to citizens in the conditions of the COVID-19 pandemic. However, despite the insufficient support from the government and financial problems, civil society organizations in the Republic of North Macedonia have continued to fulfill their mission by implementing a minimum number of projects. In this way, they made efforts to maintain their capacities and showed that, in keeping with their capabilities, they managed to provide services to the citizens even during the emergency and crisis situations of the COVID-19 pandemic.

As demonstrated in the research and in line with the theses, emphasis was placed on the role and sustainability of the capacities of the civil sector needed to carry out further activities. In the conditions of a crisis situation, the problem of sustainability of the citizens' associations and the smaller foundations was considered. It was expressed by the issue of facing financial difficulties to cover the minimum wages and the administrative costs for the staff. Analyses showed that in the nongovernmental organizations - respondents (who were a representative sample), there was no significant reduction in terms of parameters for employees, which indirectly indicates that the situation in the civil sector is not alarmingly critical and there is still no danger upon their survival despite their concerns about it.

The research provided qualitative confirmation of this in the form of information from the interviewees that some civil society organizations in the Republic of North Macedonia have been maintaining their stability to some extent, while the rest face complete cessation of their activities or suffer negative implications in a not specified period. 
The average level of motivation is a confirmation that the organizations are making efforts to continue working despite the inadequate working conditions which are directly or indirectly due to the pandemic. The main efforts in the struggle to survive so far have been aimed at finding funds through external funds and donations which are different from government institutions.

Expectations of the civil sector are to work towards meeting the critical needs the country is facing while dealing with the great damage caused by the COVID-19 crisis and the protocols and restrictions imposed by the government.

Some of these restrictions have burdened the cooperation and correspondence with their partners. The focus of the NGO was to adapt to the new technological possibilities by holding meetings, presentations and webinars through social networks (Facebook, Viber, phone calls, e-mails and other Internet platforms).

However, due to the already mentioned limitations in the research, there are not enough data on the success and efficiency of the associations in achieving and implementing their mission.

\section{Recommendations}

Lessons learned from the research provided in a form of recommendations should be taken and further used for other research and for application in practice. They prove that in order to realize the action plan and mission of the associations and foundations, they should reorganize services in such a form to respond to the needs of the users, i.e. gradual adjustment of the already prepared plans and programs in order to survive and retain employees and volunteers in NGOs. Hence, the recommendations for the NGOs are as follows:

- Adaptation of the tasks and activities of the non-governmental organizations according to the provisions of the adopted protocols of behavior in conditions of COVID-19 pandemic.

- Increasing the coordinated activities between citizens' associations and government institutions and bodies, as well as strengthening the cooperation with other domestic and foreign non-governmental organizations and donors.

- Establishment of a round cycle of cooperation by providing assistance among all participants in a process of regular exchange of 
information and advice to overcome problems they face. This process should be established by alternative ways of communication and with staff working from home via Skype, Viber, Facebook and the like.

- Replacing the traditional way of attending conferences and seminars with the so-called online conferences and webinars established remotely. Retroactively this would help reduce travel and accommodation costs and save time.

- Establishment of an external expert team of domestic and international representatives tasked to supervise and control distribution of funds from government sources to the civil sector. In this way, an independent and impartial control over the distribution of funds would be made to supervise published calls for project activities related to the COVID-19.

- When preparing assessments, analyses, and information by government institutions and bodies related to dealing with the consequences of the COVID-19 pandemic, it is necessary to take into account suggestions and considerations from a wider circle of representatives of the civil sector. Hence, the trust and cooperation between the institutions and the non-governmental sector would be raised to a higher level. In parallel, the engagement of citizens' associations in activities in the initial stages would increase the efficiency in dealing with the crisis at all levels further, which would indirectly contribute to their sustainability in a long run.

- Part of the assistance from donors to the civil sector could be in a form of material and technical means such as computers and other equipment as one of the assistance options that would further provide more efficient services to citizens.

In certain cases, it would be more beneficial for the non-governmental organizations to reallocate certain capacities and resources available to the donors and thus make them directly available to the needs of the citizens. Thus, the civil sector would have the role of mediator and organizer of activities and that would be another way to improve efficiency and increase the benefits that lead to positive sustainability of citizen's associations.

Regarding the part of the recommendations that refer to the donors (state and non-state) in emergency situations, it should be emphasized that they should show greater commitment to the support of the civil sector. Hence, that would mean greater transparency in the allocation 
of funds from public calls for grants. At the same time the dynamics in finding and allocating additional funds in order to support the sustainability of the civil sector should be intensified.

Anyway, in this critical period of dealing with the COVID 19 pandemic, it is recommended that NGOs, within the limits of their capabilities and in accordance with their missions and tasks, continue to be available for social needs and to intensify their activities, especially around voluntary participation. Their efforts should be focused on finding additional funding opportunities different from traditional ways of announcing a public call but also by creating and carrying out some activities that will enable self-financing. This will allow greater independence from external sponsorships.

Finally, the non-governmental sector should initiate and show the will for more intensive cooperation with state institutions. In case of a common threat such as the COVID 19 pandemic, they need to be made available to government needs and work together to reverse the effects of the pandemic.

\section{Bibliography}

1. Ballestros and Gatignon,(2019). Best Practice of Nongovernmental Organizations in Combating COVID 19.

2. Bekkers and Wiepking, (2011). A Literature Review of Empirical Studies of Philanthropy: Eight Mechanisms That Drive Charitable Giving.

3. Burton Weisbrod, (1975). Public good theories of the non-profit sector: Weisbrod revisited.

4. FES, (2020). Pandemic Causes Further Centralization of Power and Political Polarisation in the WB, European Western Balkans.

5. Islam A.C. (2016). Non-Governmental Organization Vulnerabilities: Donors and Resource Dependence. (p.37).

6. Nemțeanu1, S.M. \& Dabija D.C. (2020). Best Practices of Nongovernmental Organisations in Combating COVID-19, 6th BASIQ International Conference on New Trends in Sustainable Business and Consumption. Messina, Italy (p. 3).

7. https://www.researchgate.net/publication/341447271 BEST_PRACTICES_OF_NONGOVERNMENTAL_ ORGANISATIONS_IN_COMBATTING_COVID-19 
8. Neshikj, I\&Spasovska, B. (2020). Filling Democracy's Gaps in the Western Balkans.

9. https://carnegieeurope.eu/2020/12/07/filling-democracy-s-gapsin-western-balkans-pub-83147

10. Portney and Cuttler, (2010). The Local Nonprofit Sector and the Pursuit of Sustainability in American Cities: A Preliminary Exploration.

11. https://europeanwesternbalkans.com/2020/04/27/fes-pandemic-causes-further-centralisation-of-power-and-political-polarisation-in-the-wb/

13. SchwartzandYen,(2017). Towardacollaborativemodelofpandemicpreparedness and response: Taiwan's changing approach to pandemics.

\section{COVID - 19 i njegov uticaj na održivost organizacija civilnog društva u regionu Zapadnog Balkana}

Apstrakt: Autoriovestudije nastojali su da prikažu uticaj koji COVID 19 ima na sektor civilnog društva u Republici Severnoj Makedoniji. U ovoj složenoj situaciji oni su se fokusirali na raspodelu sredstava. Pored toga, saradnja između vladinih institucija i udruženja građana $u$ sprovođenju aktivnosti kako bi se izašlo na kraj sa pandemijom takođe je istražena. Analize sadržaja primenjene su kako bi se ispitali propisi kojima se reguliše učešće organizacija građana u kontekstu pandemije. Pored toga, komparativne metode primenjene su da bi se odredio stepen uključenosti NVO u korišćenje budžeta i ostalih doniranih sredstava. Napokon, korišćene su kvalitativne metode da bi se procenilo da li su ta sredstva pravi izbor udruženja u kontekstu njihove održivosti $i$ stvaranja prilika da nastave sa aktivnostima.

Posmatrajući rad u celini, stiče se utisak da je neophodno obuhvatnije istraživanje sa većim brojem respondenata. Tako će se, kroz studiju slučaja, doći do odgovora na pitanje da li su ove NVO neprofitne ili ne. Takođe, da li u određenom periodu one realizuju određene ciljeve vlade ili druge interese profitirajući direktno ili indirektno po raznim osnovama.

Konačno, autori daju konkretne zaključke i preporuke za utvrđivanje mogućeg daljeg toka akcije u smislu transparentnijeg, efikasnijeg $i$ sveobuhvatnijeg rada NVO.

Istraživanje je rađeno 2021. godine uz podršku Fonda za Zapadni Balkan i Ministarstva spoljnih poslova Japana.

Ključne reči: NVO, COVID-19, pandemija, održivost. 